\title{
Affiliation among Infantile Age, Morbidity and Prakriti (Physical Constitution): A Longitudinal Preliminary Study
}

\author{
Srivastava Niraj ${ }^{1 *}$, Gehlot Sangeeta ${ }^{2}$ and Singh B. M. ${ }^{3}$ \\ 'Department of Kaumarbhritya/Balroga, Government Ayurvedic PG College and Hospital (Sampurnanand \\ Sanskrit University), Varanasi - 221002, Uttar Pradesh, India; nirajimsbhu@gmail.com \\ 2Department of Kriya Sharir, FOAy, IMS, BHU, Varanasi - 221005, Uttar Pradesh, India \\ ${ }^{3}$ Department of Kaumarbhritya/Balroga, FOAy, IMS, BHU, Varanasi - 221005, Uttar Pradesh, India
}

\section{Abstract}

Background: Prakriti has important role in prevention, diagnosis, treatment of disease and forecast of future disorders. Infants are more prone to develop various health problems like infections, due to poor immune system. This study shows relation between infantile age morbidity and their Prakriti (physical constitution) in present scenario. Material and Methods: For this longitudinal study 100 infants were registered for Prakriti assessment and their relationship with incidence of diseases. Performa for Prakriti assessment in infants was developed by Department of Kaumarbhritya/Balroga and Department of Kriya Sharira. This study was conducted in Kaumarbhritya OPD, SS Hospital, Banaras Hindu University (BHU). Observation and Result: In the present study, rate of morbidity in infantile age was found maximum in Vata Prakriti (6.6 episodes/infant/year) and minimum in Kapha Prakriti (1.54 episodes/infant/year). Incidence of morbidity was 2.41 episodes/infant/year. The commonest morbidities were respiratory tract infections (40.66\%) and diarrhea (30.29\%). Respiratory tract infection is most common morbidity in Vata Prakriti (33.3\%), Kapha Prakriti (73.5\%), Vata-Pitta Prakriti (48.1\%) and Vata Kapha Prakriti (53.3\%) infants. Diarrhea was the most common morbidity in Pitta Prakriti (32.2\%) and Pitta-Kapha Prakriti (50.0\%) infants. Discussion and Conclusion: Rate of morbidity was found more in Vata Prakriti and less in Kapha Prakriti infants which justifies the concept of Ayurveda that feature of Vata Prakriti is Shighravikara and Kapha Prakriti have Ashighravikara. Vata and Kapha Prakriti infants mostly suffer from respiratory tract infection and Pitta Prakriti infants mostly suffer from diarrhea. In present study incidence of morbidity was 2.41 episodes/infant/year and most common morbidity was respiratory tract infection and diarrhea.

Keywords: Ayurveda, Diarrhea, Infants, Respiratory Tract Infection, Vata-Pitta-Kapha

\section{Introduction}

Prakriti is an important concept of Ayurveda that enlightens individuality and expresses unique trait of an individual that is defined by specific and permanent composition of Dosha at conception. These specific types of Doshika Prakriti can be identified in growing individuals ${ }^{1}$. The knowledge about the Prakriti helps in diagnosis of diseases ${ }^{2}$, management of disease ${ }^{3}$ and forecast of Dosha dependent disorders in future ${ }^{4}$.
Knowledge of Prakriti can guide the parents for prevention of expected disorders and deciding to choose carrier at a very early age ${ }^{5}$. Sama Prakriti has good resistance and not prone to develop diseases ${ }^{6}$ but existence of this Prakriti is very rare. Another category is single Dosha dominant and mixed of two Dosha in which one is less dominant. Amongst these Vata, Pitta and Kapha Prakriti individuals frequently fall sick i.e. most vulnerable to diseases and in decreasing order ${ }^{7}$. Those constitutions which formed by two Dosha together are 
also sick and they have to be treated with difficulty ${ }^{8}$. When Dosha of body are not in equilibrium state, it can be termed as stage of Vikriti $^{9}$ (disease state) or state of morbidity/pathological conditions. The morbidity rate is the frequency or proportion with which a disease appears in a population.

Vata Prakriti children are more prone to develop diseases of the neurological system especially related to motor functions. These diseases are more pronounced also in old age which is the period of Vata. Pitta is responsible for various metabolic activities taking place in the body. Pitta Prakriti children are more prone towards diseases of digestive and metabolic systems. Pitta disorders are pronounced in the middle age which is the period of Pitta. Children with Kapha Prakriti are prone to disorder of the respiratory system especially phlegmatic disorders and growth aspects ${ }^{10}$. In Kapha Prakriti the disease affects mainly upper part of the body. These disorders are pronounced in early age which is period of Kapha Kala. The Dwandaja Prakriti have combination of any two Dosha and susceptible to diseases of both types of the Dosha. It is mentioned in Ayurveda that these types are worst in terms of health due to combination of opposite qualities and thereby selection of drugs to combat the same is a difficult task especially for children of Pitta-Kapha predominance ${ }^{11}$. Infants comprise $2.92 \%$ of the Indian population ${ }^{12}$. Infants are more prone to develop various health problems like infections, due to poor immune system ${ }^{13}$.

The present study was planned to find out the incidence of diseases and pattern of diseases in infants and relationship with their Prakriti (physical constitution). Outcome of this work regarding the trend of disease, impact on health for further planning and implementation is a need of the hour.

\section{Material and Methods}

\subsection{Selection of Patients}

This longitudinal study was carried out in Kaumarbhritya/ Balroga, O.P.D., Sir Sunderlal Hospital, Institute of medical sciences (I.M.S), Banaras Hindu University (B.H.U) after obtaining approval from the institutional ethics committee. The infants were selected after written informed consent and after offering sufficient explanation about the study and its aims. After proper screening Prakriti assessment was done on $10^{\text {th }}$ day of life in healthy state as per predesigned performa of research work. Incidence of disease was followed up for one year. Follow up visits were done according to vaccination schedule and enquired about their morbidities, followed by a detailed clinical examination. Documents verification was also done in case the child had illness in between the follow ups.

\subsection{Ethical Clearance}

The ethical committee clearance number is dean/ 2011-12/392-A dated 12/12/2011. Cases were selected on the basis of following inclusion and exclusion criteria;

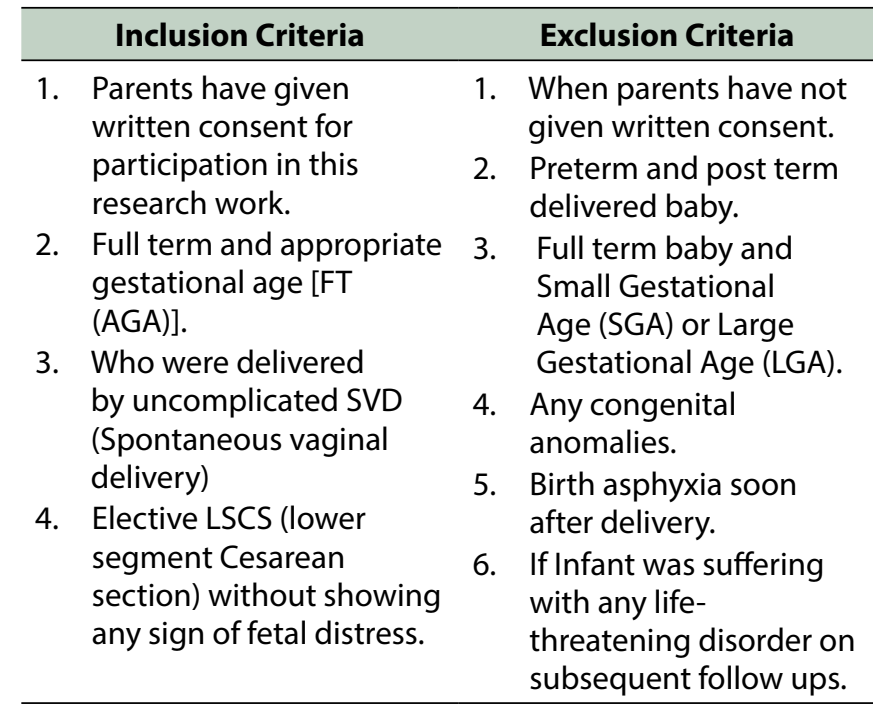

\subsection{Assessment of Prakriti}

For this study, a questionnaire was prepared on the basis of Prakriti characteristic mentioned in different textbooks of Ayurveda ${ }^{14-21}$. In questionnaire, only those Doshika characteristics were taken, which were possible to assess in infantile age group; while the others characteristics related to the adults were excluded. Assessment was made by analyzing obtained data filled by questionnaire and physical examination of infants. All concerned characteristics were assessed by Trividha pariksha of Ayurveda as Darshan (inspection), Sparshana (palpation) and Prashana (questions) 22,23 . Scores of Vata, Pitta and $K a p h a(\mathrm{~V} / \mathrm{P} / \mathrm{K})$ in an individual were scored by using a $0 / 1$ against $\mathrm{V} / \mathrm{P} / \mathrm{K}$ for each of the questions depending on no or yes answer respectively and cumulative scores 
of $\mathrm{V}, \mathrm{P}$ and $\mathrm{K}$ are calculated through the computer generated software ${ }^{24}$. No infant, having Sama-prakriti or Tridoshaja Prakriti, was observed during this study.

\subsection{Diagnosis of Diseases}

In this study respiratory tract infection (RTI), diarrhoea, skin infection, abdominal colic and urinary tract infection (UTI) which are commonly seen during infantile age group were observed. Diagnosis of these diseases was done on the basis of clinical presentation in infants. Monthly follow up visits were done to enquire about their morbidities, followed by detail clinical examination. Infants who had illness in between the visits were also included in the study. Data analysis was done by using SPSS software version 22.0.

\section{Observations and Results}

Total 100 infants, irrespective to sex were registered on $10^{\text {th }}$ day of life and Prakriti of registered infants was assessed. In this study, rate of disease incidence, relation between Prakriti and disease incidence as well as relation between Prakriti and type of disease were observed.

Highest incidence density was seen in respiratory tract infection (RTI) at 0.98 per infant per year (Figure 1) (40.66\%), diarrhea at $0.73(30.29 \%)$, skin infection at $0.34(14.10 \%)$, abdominal colic at 0.18 (7.4\%) and urinary tract infection at (UTI) 0.13 (5.39\%) (Table 1).

Highest incidence of diseases was found in Vata Prakriti and Pitta Prakriti but lowest incidence of diseases

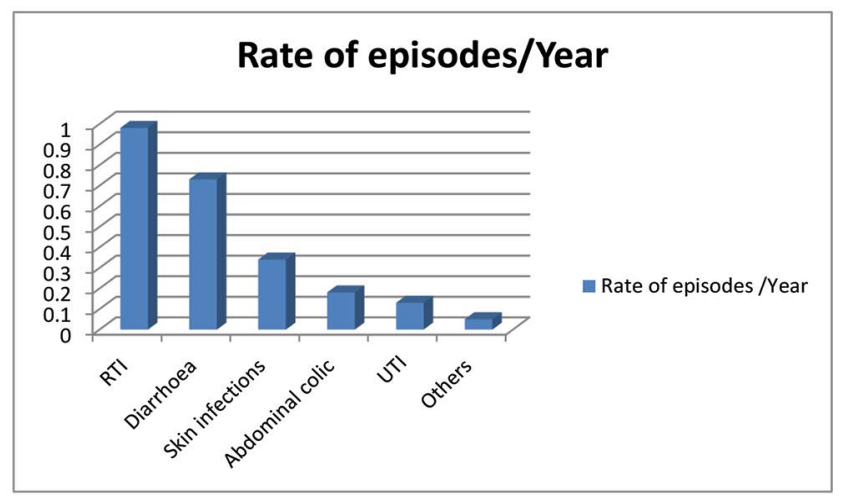

Figure 1. Showing the rate of episodes/year against different types of morbidity. was found in Kapha Praktiti and Pitta-Kapha Prakriti (Figure 2). Vata-Pitta Prakriti and Vata-Kapha Prakriti have near to equal frequency of diseases incidence (Table 2). Overall incidence rate of morbidity was 2.41 episodes per infant per year.

Highest morbidity in Vata Prakriti infants (33.3\%) and Vata-Kapha Prakriti infants (53.3\%) was respiratory

\section{Table 1. Rate of disease incidence in a year} among infants $(n=100)$

\begin{tabular}{ccc}
\hline Type of morbidity & $\begin{array}{c}\text { Number of } \\
\text { episodes }\end{array}$ & $\begin{array}{c}\text { Number of } \\
\text { episodes / Year }\end{array}$ \\
\hline Respiratory tract infection & 98 & 0.98 \\
(RTI) & 73 & 0.73 \\
Diarrhea & 34 & 0.34 \\
Skin infections & 18 & 0.18 \\
$\begin{array}{c}\text { Abdominal Colic } \\
\text { Urinary tract infection } \\
\text { (UTI) }\end{array}$ & 13 & 0.13 \\
Others & 05 & 0.05 \\
\hline
\end{tabular}

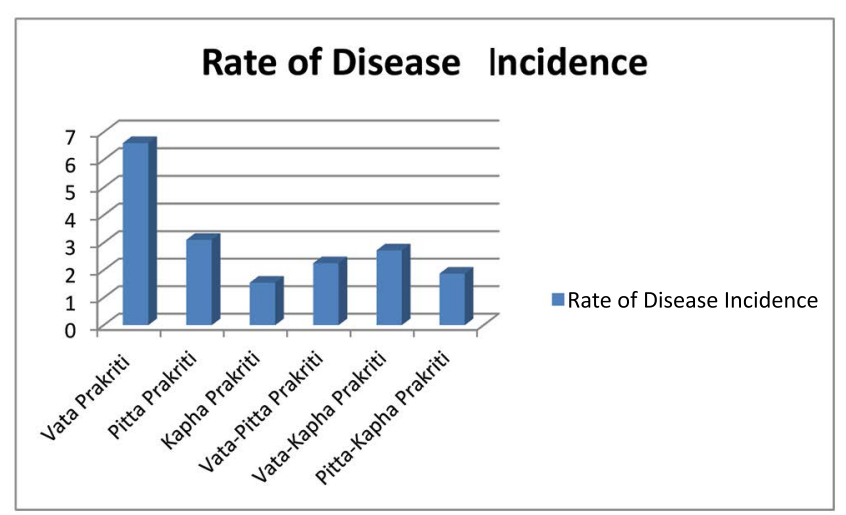

Figure 2. Showing the rate of disease incidence in different Prakriti constitution.

tract infection and skin infection. Highest morbidity in Pitta Prakriti infants (32.2\%) and Pitta-Kapha Prakriti infants $(50.0 \%)$ was diarrhea and respiratory tract infection. Highest morbidity in Kapha Prakriti infants (73.5\%) and Vata-Pitta Prakriti infants (48.1\%) was respiratory tract infection and diarrhea. (Table 3 ). 
Table 2. Relation between Prakriti and morbidity rate

\begin{tabular}{llll}
\hline Prakriti & No. of Infants & $\begin{array}{l}\text { Frequency of } \\
\text { diseases }\end{array}$ & $\begin{array}{l}\text { Rate of morbidity } \\
\text { (Diseases /year) }\end{array}$ \\
\hline Vata Prakriti & 05 & 33 & 6.6 times/year \\
Pitta Prakriti & 19 & 59 & 3.10 times/year \\
Kapha Prakriti & 22 & 34 & 1.54 times/year \\
Vata-Pitta Prakriti & 12 & 27 & 2.25 times/year \\
Vata-Kapha Prakriti & 11 & 30 & 2.72 times/year \\
Pitta-Kapha Prakriti & 31 & 58 & 1.87 times/year \\
\hline
\end{tabular}

Table 3. Relation between Prakriti and type of morbidity

\begin{tabular}{llllllll}
\hline \multicolumn{7}{l}{ Prakriti of Infants } & \multicolumn{2}{l}{ Incidence of disease type (times/year) } & $\begin{array}{lllll}\text { Respiratory tract } \\
\text { infection (RTI) } \\
\end{array}$ & Diarrhea & $\begin{array}{l}\text { Skin } \\
\text { infections }\end{array}$ & $\begin{array}{l}\text { Abdominal } \\
\text { Colic }\end{array}$ & $\begin{array}{l}\text { Urinary tract } \\
\text { infection (UTI) }\end{array}$ & Others & Total \\
\hline Vata $(\mathrm{n}=5)$ & $11(33.3 \%)$ & $7(21.2 \%)$ & $9(27.3 \%)$ & $4(12.1 \%)$ & $0(0 \%)$ & $2(6.1 \%)$ & 33 \\
Pitta $(\mathrm{n}=19)$ & $14(23.7 \%)$ & $19(32.2 \%)$ & $7(11.8 \%)$ & $9(15.2 \%)$ & $7(11.8 \%)$ & $3(5.1 \%)$ & 59 \\
Kapha $(\mathrm{n}=22)$ & $25(73.5 \%)$ & $4(11.7 \%)$ & $0(0.0 \%)$ & $2(5.8 \%)$ & $3(8.8 \%)$ & $0(0.0 \%)$ & 34 \\
Vata-Pitta $(\mathrm{n}=12)$ & $13(48.1 \%)$ & $9(33.3 \%)$ & $3(11.1 \%)$ & $1(3.7 \%)$ & $1(3.7 \%)$ & $0(0.0 \%)$ & 27 \\
Vata-Kapha $(\mathrm{n}=11)$ & $16(53.3 \%)$ & $5(16.6 \%)$ & $7(23.3 \%)$ & $2(6.6 \%)$ & $0(0.0 \%)$ & $0(0.0 \%)$ & 30 \\
Pitta-Kapha $(\mathrm{n}=31)$ & $19(32.7 \%)$ & $29(50.0 \%)$ & $8(13.7 \%)$ & $0(0.0 \%)$ & $2(3.4 \%)$ & $0(0.0 \%)$ & 58 \\
\hline
\end{tabular}

\section{Discussion and Conclusion}

Prakriti has decisive role in restoration of health, which is the prime objective of Ayurveda. Maximum morbidity was seen in Vata Prakriti infants (6.6 episodes/infants/ year) and minimum in Kapha Prakriti (1.54 episodes/ infants/year) which justifies the concept of Ayurveda that, feature of Vata Prakriti is Shighravikara and Kapha Prakriti have Ashighra vikara ${ }^{25}$.

All infants of Vata Prakriti were frequently suffering from respiratory tract infection and skin infection which justify the concept of Ayurveda that characteristic of Pratatsitataudvepak Stambha ${ }^{26}$ (Continuously infliction with cold, shivering and stiffness) and dry nature of skin in Vata Prakariti infants. Dryness of the skin is due to its increased $\mathrm{pH}$ value because raised $\mathrm{pH}$ value reflects cutaneous irritation and may provide media for growth of bacterial flora of the skin. So, Vata Prakriti individual's skin are more prone for skin related diseases such as atopic dermatitis and candida infection because increased $\mathrm{pH}$ value reduces the antibacterial and antimycotic properties of the skin surface, which enables more frequent occurrence of skin infection ${ }^{27,28}$.

In present study incidence of morbidity was 2.41 episodes/infant/year and these data are similar with the study done in semi-urban area of Delhi, where incidence of morbidity was found 3.1 per infants per year ${ }^{29}$. Commonest morbidity in infancy was respiratory tract infection (40.66\%) and after that diarrhea (30.29\%). This data is very much similar to an earlier study ${ }^{30}$ where commonest morbidity in infantile age is RTI and diarrhea but conversely, other studies ${ }^{31,32}$ show that diarrhea is most common morbidity in infantile period than skin and eye infection, this variation may be due to local environmental factors.

\section{Limitations}

This study was done on limited number of infants due to time limitation for our research work. To make it more clear this study requires large number of infants 
to access the prakriti in relation to disease incidence and morbidity.

\section{Acknowledgements}

The authors wish to thanks all the parents of infants who give consent to participate in this study.

\section{Source of Support: Nil}

\section{Conflict of Interest: None Declared}

\section{References}

1. Agnivesha. Charaka samhita, English translation by Sharma RK, Dash B. Vol-II, Viman Sthan (8:95), Chaukhambha Sanskrit series office, Varanasi. 2010.

2. 'Agnivesha. Charaka samhita, English translation by Sharma RK, Dash B. Vol-II, Viman Sthan (6:16), Chaukhambha Sanskrit series office, Varanasi. 2010.

3. Agnivesha. Charaka samhita, English translation by Sharma RK, Dash B. Vol-1, Sutra Sthan (10:11), Chaukhambha Sanskrit series office, Varanasi. 2010.

4. Vagbhata. Astanga Hriday, English translation by Srikantha Murty KR, Vol-I, Sutra Sthana (1:10), Chaukhambha, Krishnadas Academy Varanasi. 2015.

5. Srivastava Niraj, Singh Praguna, Gehlot Sangeeta, Singh Sanjay, Singh BM. Basics for the development of prototype research software relevant to infants' Prakriti assessment for Vikriti management and possible future disorders. Int. J. Res. Ayurveda Pharm. 2017; 8 (Suppl 1).

6. Vagbhata. Astanga Hriday, English translation by Srikantha Murty KR, Vol-I, Sutra Sthana (1:10), Chaukhambha, Krishnadas Academy Varanasi. 2015.

7. Agnivesha. Charaka samhita, English translation by Sharma RK, Dash B. Vol-1, Sutra Sthan (7:40), Chaukhambha Sanskrit series office, Varanasi. 2010.

8. Vagbhata. Astanga samgraha, English translation by Srikantha Murty KR, Vol-II, Sharir Sthana, (8/15), Chaukhambha Orientalia, Varanasi. 2001.

9. Agnivesha. Charakasamhita, English translation by Sharma RK, Dash B. Vol-1, Viman Sthan (8:101), Chaukhambha Sanskrit series office, Varanasi. 2010.

10. Piyush Kumar Tripathi, Sangeeta Gehlot. A Physioanatomical study of Prakriti, ID- 21024805. Available at http://www.luiu.com. 2017.
11. Agnivesha. Charaka samhita, English translation by Sharma RK, Dash B. Vol-1, Viman Sthan (7:39-41), Chaukhambha Sanskrit series office, Varanasi. 2010.

12. Park K. Text book of preventive and Social Medicine, 18th ed. Jabalpur; Banarsidas Bhanot Publishers. 2005; 2:391.

13. Kumar A. Primary newborn care. Health Action. 2002; 15:5-6.

14. Agnivesha. Charaka samhita, English translation by Sharma RK, Dash B. Vol-1, Viman Sthan (8:96-100), Chaukhambha Sanskrit series office, Varanasi. 2010.

15. Sushruta. Sushruta samhita, English translation by Sharma P.V, Vol II, Sharir Sthana (4:64-76), Chaukhambha Vishvabharati, Varanasi. 2005.

16. Vagbhata. Astanga samgraha, English translation by Srikantha Murty KR, Vol-II, Sharir Sthana, (8/6-14), Chaukhambha Orientalia, Varanasi. 2001.

17. Vagbhata. Astanga Hridaya, English translation by Srikantha Murty KR, Vol-I, Sharir Sthana (3:85-103), Chaukhambha, Krishnadas Academy Varanasi. 2015.

18. Bhavmishra. Bhav prakasha, commentary and English translation by Sitaram Balusu, Chunekar KC, Vol-I Purvakhanda 4:54-58, Chaukhambha Orientalia, Varanasi. 2006.

19. Sharangadharacharya. Sharngadhara samhita English translation by Rao G. Prabhakar, 1st edition, Purvakhanda (6:21-23), Chaukhambha Sanskrit sansthan, Varanasi. 2013.

20. Harita. Harita samhita English translation by Pandey Gyanendra, Vol-1, Pratham-Sthana 5:17-22, Chaukhambha Sanskrit series office, Varanasi. 2016.

21. Bhela, Bhela samhita. English translation by Krishnamurty KH, Viman Sthana, 4:16-25, Chaukhambha Vishvabharati , Varanasi. Reprint year 2008.

22. Sushruta. Sushrutasamhita, English translation by Sharma PV, Vol I, Sutra Sthan (10:4), Chaukhambha Vishvabharati , Varanasi. 2005.

23. Vagbhata. Astanga samgraha, English translation by Srikantha Murty KR, Vol-I, Sutra Sthana, (1/45.1), Chaukhambha Orientalia, Varanasi. 2001.

24. Srivastava N, Gehlot S, Singh S, Singh BM. Do the anthropometric parameters vary as per Prakriti (Physical constitution) of Infants; International Journal of Innovative Knowledge Concepts. 2017 December; 5(12).

25. Agnivesha. Charaka samhita, English translation by Sharma RK, Dash B. Vol-1, Viman Sthan (8:96-98), Chaukhambha Sanskrit series office, Varanasi. 2010.

26. Agnivesha. Charaka samhita, English translation by Sharma RK, Dash B. Vol-1, Viman Sthan (8:98), Chaukhambha Sanskrit series office, Varanasi. 2010.

27. FluhrJW,DarlenskiR, TaiebA,HachemJP,BaudouinC,Msika $\mathrm{P}$, et al. Functional skin adaptation in infancy almost complete but not fully competent. Exp Dermatol. 2010; 19:1-10. https://doi.org/10.1111/j.1600-0625.2009.01023.x 
28. Srivastava N, Gehlot S, Singh S, Singh BM. Application of different parameters for selecting normal and abnormal skin characteristics in determination of Prakriti in infants. Int. J. Res. Ayurveda Pharm. 2015; 6(2):161-8. https://doi. org/10.7897/2277-4343.06232

29. Gulati PV. An epidemiological study of morbidity pattern. Indian Pediatrics. 1977; XIV: 93-7.

30. Nitin Joseph, Subba SH, Vijaya A Naik, Mahantshetti NS and Mallapur MD. Morbidity among Infants in South India: A Longitudinal Study. Indian Journal of Pediatrics. 2010 April; 77.
31. Vaahtera M, Kulmala T, Maleta K, Cullinan T, Salin ML, Ashorn P. Epidemiology and predictors of infant morbidity in rural Malawi. Paediatric and Perinatal Epidemiology. 2000; 14:363-71. https://doi.org/10.1046/ j.1365-3016.2000.00308.x

32. Ahmed HM, El-Sherbini AF, Fahmy SI, Mortada MM, Nosseir SA, Elsahn FF. A prospective study of morbidity pattern and nutritional status of a group of healthy newborns during the first year of life in a rural area near Alexandria. J Egypt Public Health Association. 1991; 66:253-77. PMid:1800623 